\title{
New enamine derivatives of lapachol and biological activity
}

\author{
MAILCAR F. OLIVEIRA ${ }^{1}$, TELMA L.G. LEMOS ${ }^{1}$, MARCOS C. DE MATTOS $^{1}$, \\ TACIANA A. SEGUNDO ${ }^{2}$, GILVANDETE M.P. SANTIAGO ${ }^{2}$ \\ and RAIMUNDO BRAZ-FILHO ${ }^{3}$ \\ ${ }^{1}$ Departamento de Química Orgânica e Inorgânica, Universidade Federal do Ceará \\ Cx. Postal 12200, 60451-970 Fortaleza, Ceará, Brazil \\ ${ }^{2}$ Departamento de Farmácia, Universidade Federal do Ceará \\ ${ }^{3}$ Setor de Química de Produtos Naturais-LCQUI-CCT, Universidade Estadual do Norte Fluminense \\ 28015-620 Campos, Rio de Janeiro, Brasil \\ Manuscript received on February 19, 2001; accepted for publication on December 6, 2001; \\ contributed by RAIMUNDO BRAZ-FILHO*
}

\begin{abstract}
A convenient synthesis of the new enamine derivatives 2-(4-morpholinyl)-3-(3-methyl-2-butenyl)-1,4naphthalenedione, 2-(1-piperidinyl)-3-(3-methyl-2-butenyl)-1,4-naphtalenedione and 2-(1-pyrrolidinyl)-3(3-methyl-2-butenyl)-1,4-naphthalenedione was carried out from natural 2-hydroxy-3-(3-methyl-2-butenyl)1,4-naphthalenedione (lapachol) and morpholine, piperidine and pyrrolidine. The structures of the products were established mainly by NMR analysis, including 2D experiments. Biological activities of these products were evaluated against Artemia salina, Aedes aegypti and cytotoxicity using A549 human breast cells.
\end{abstract}

Key words: lapachol, enamine derivatives, biological activities.

\section{INTRODUCTION}

Lapachol (1) is a natural quinone (see Figure 1) which has been isolated in very good yield from several species of Bignoniaceae found in Brazil, including Ceará State, where the species Tabebuia serratifolia is popularly known as "ipê-amarelo" (Correia 1984). From an ethanolic bark extract of a specimen of Tabebuia serratifolia lapachol (1) was obtained in $2.9 \%$ yield (Fernandes-de-Oliveira 2000).

Several biological activities are reported for this natural quinone, including anti-cancer, antiviral, antimicrobial, analgesic, antiinflammatory, antimalarial, cercaricidal, schistosomicidal and also a potential activity against Trypanosoma cruzi, the causal agent of Chagas' disease (Carvalho et al.

Correspondence to: Raimundo Braz-Filho

E-mail: braz@uenf.br

*Member of Academia Brasileira de Ciências
1988, Driscoll et al. 1974, Grazziotin et al. 1992, Lagrota 1983, Lopes et al. 1978, Pinto et al. 1977, 1987).

Nitrogen containing indoloquinone derivatives have been recently evaluated as novel anticancer agents, and the amine moiety was identified as an important feature for oxic and hipoxic potency and for the ability to act as a substract for reductase enzymes (Naylor et al. 1997).

Aedes aegypti is the vector for the transmission of "yellow fever" or "dengue" and it is responsible for the contamination of the urban population in developing countries, specifically in Brazil, causing serious public health hazards (Pan American Health Organization 1994).

This prompted us to synthesize new nitrogen lapachol derivatives in order to examine their larvicidal activities against Aedes aegypti and Artemia 
<smiles>CC(C)=CCC1=C(O)C(=O)c2ccccc2C1=O</smiles>

1

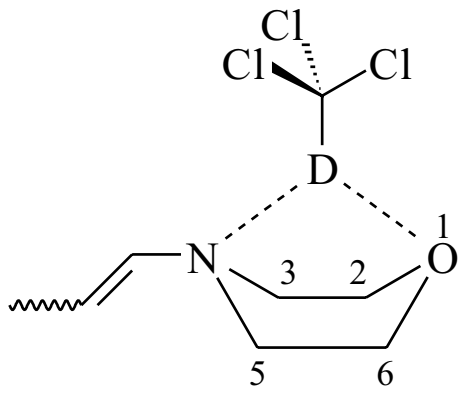

Z- $(8 \mathbf{a})$ and $E-(10 \mathbf{a})$<smiles>[R]C1=C(C=C(C)C)C(=O)c2ccccc2C1=O</smiles><smiles>[R]N1[14CH2][CH][14CH2]O[14CH2]1</smiles><smiles>[R]N1[C]CC[C]1</smiles><smiles>[R]CN1CCCC1</smiles>

Fig. 1 - Structures lapachol (1), lapachol derivatives $(\mathbf{2 , 3 , 4})$ and model compounds $\mathbf{8}$ and $\mathbf{1 0}$ involved in intermolecular hudrogen bond with $\mathrm{CDCl}_{3}(\mathbf{8 a}$ and 10a).

salina as well as cytotoxicity against A549 human breast tumor cells.

\section{MATERIALS AND METHODS}

\section{General Experimental Procedure}

Melting points (mp) were determined on a Mettler FP5 apparatus and are uncorrected. ${ }^{1} \mathrm{H}$ - and ${ }^{13} \mathrm{C}$ NMR spectra were obtained on a Bruker Avance DRX $500 \mathrm{MHz}\left(500 \mathrm{MHz}\right.$ for ${ }^{1} \mathrm{H}$ and $125 \mathrm{MHz}$ for $\left.{ }^{13} \mathrm{C}\right)$ spectrometer. IR spectra were run on a PerkinElmer 1000 FT-IR spectrometer using $\mathrm{KBr}$ pellets. Lapachol (1) was obtained from an ethanolic extract of the bark of a specimen of Tabebuia serratifolia Bertol, Bignoniaceae, collected in Mulungu, Ceará, Brazil.

\section{General Procedure for Derivatives}

In a typical experiment, a solution of lapachol (1, $100 \mathrm{mg}, 0.41 \mathrm{mmol}$ ) in freshly redistilled amine (35 $\mathrm{mmol}$ ) was stirred for $6 \mathrm{~h}$ at room temperature and the exceeding amine was evaporated under vacuum. The residue was recrystallized from a mixture of EtOAc/hexane to yield 2 (94\%), 3 (79\%) and 4 $(77 \%)$.

\section{2-HYDROXY-3-(3-METHYL-2-BUTENYL)-}

\section{1, 4-NAPHTHALENEDIONE (1)}

Yellow solid, $\mathrm{mp} 139-140^{\circ} \mathrm{C}$. IR $\left(\mathrm{cm}^{-1}, \mathrm{KBr}\right): v_{\max }$ $3353(\mathrm{O}-\mathrm{H}), 1657(\mathrm{C}=\mathrm{O}), 1642(\mathrm{C}=0), 1592$ (aromatic ring), 1273 (C-O). ${ }^{1} \mathrm{H}-\mathrm{NMR}(500 \mathrm{MHz}$, $\left.\mathrm{CDCl}_{3}\right)$ : see Table I; ${ }^{13} \mathrm{C}-\mathrm{NMR}\left(125 \mathrm{MHz}, \mathrm{CDCl}_{3}\right)$ : see Table II. 


\section{TABLE I}

${ }^{1}$ H NMR spectral data for lapachol (1) and the enamine derivatives 2-4. Chemical shifts in $\delta_{\mathbf{H}}(\mathbf{p p m})$ and coupling constants $\left(J\right.$, in parenthesis) in $\mathrm{Hz}$, in $\mathrm{CDCl}_{3}$ and TMS as internal standard.*

\begin{tabular}{c|c|c|c|c}
\hline $\mathrm{H}$ & 1 & 2 & 3 & 4 \\
\hline 5 & $8.07(\mathrm{~d}, J=7.5)$ & $8.07(\mathrm{~d}, J=7.4)$ & $8.03(\mathrm{~d}, J=7.5)$ & $8.02(\mathrm{~d}, J=7.5)$ \\
6 & $7.70(\mathrm{t}, J=7.5)$ & $7.68(\mathrm{t}, J=7.4)$ & $7.59(\mathrm{t}, J=7.5)$ & $7.58(\mathrm{t}, J=7.5)$ \\
7 & $7.62(\mathrm{t}, J=7.5)$ & $7.60(\mathrm{t}, J=7.4)$ & $7.47(\mathrm{t}, J=7.5)$ & $7.45(\mathrm{t}, J=7.5)$ \\
8 & $8.02(\mathrm{~d}, J=7.5)$ & $7.98(\mathrm{~d}, J=7.4)$ & $7.85(\mathrm{~d}, J=7.5)$ & $7.84(\mathrm{~d}, J=7.5)$ \\
$1^{\prime}$ & $3.27(\mathrm{~d}, J=7.3)$ & $3.26(\mathrm{~d}, J=7.2)$ & $3.23(\mathrm{~d}, J=6.1)$ & $3.17(\mathrm{~d}, J=5.9)$ \\
$2^{\prime}$ & $5.17(\mathrm{t}, J=7.3)$ & $5.18(\mathrm{t}, J=7.2)$ & $5.18(\mathrm{~m})$ & $5.13(\mathrm{~m})$ \\
$4^{\prime}$ & $1.75(\mathrm{~s})$ & $1.73(\mathrm{~s})$ & $1.76(\mathrm{~s})$ & $1.76(\mathrm{~s})$ \\
$5^{\prime}$ & $1.64(\mathrm{~s})$ & $1.65(\mathrm{~s})$ & $1.63(\mathrm{~s})$ & $1.63(\mathrm{~s})$ \\
$6^{\prime}$ & - & $2.97(\mathrm{t}, J=4.2)$ & $3.08(\mathrm{br} \mathrm{s})$ & $3.25(\mathrm{br} \mathrm{s})$ \\
$7^{\prime}$ & - & $3.30(\mathrm{t}, J=4.2)$ & $1.61(\mathrm{br} \mathrm{s})$ & $1.94(\mathrm{br} \mathrm{s})$ \\
$8^{\prime}$ & - & - & $1.53(\mathrm{br} \mathrm{s})$ & $1.94(\mathrm{br} \mathrm{s})$ \\
$9^{\prime}$ & - & $3.30(\mathrm{t}, J=4.2)$ & $1.61(\mathrm{br} \mathrm{s}$ & $3.25(\mathrm{br} \mathrm{s})$ \\
$10^{\prime}$ & - & $2.97(\mathrm{t}, J=4.2)$ & $2.97(\mathrm{t}, J=4.2)$ & - \\
\hline
\end{tabular}

*Homonuclear 2D ${ }^{1} \mathrm{H}-{ }^{1} \mathrm{H}-\mathrm{COSY}$ and heteronuclerar $2 \mathrm{D}{ }^{1} \mathrm{H}_{-}{ }^{13} \mathrm{C}-\mathrm{COSY}-{ }^{\mathrm{n}} J_{\mathrm{CH}}(\mathrm{n}=1$, HMQC; $\mathrm{n}=2$ and 3, HMBC) were also used in these assignments (Table II).

2-(4-MORPHOLINYL)-3-(3-METHYL-2-BUTENYL)1, 4-NAPHTHALENEDIONE (2)

Dark red solid, mp 81.7-83.2 ${ }^{\circ} \mathrm{C}$. IR $\left(\mathrm{cm}^{-1}, \mathrm{KBr}\right)$ : $v_{\max } 1659(\mathrm{C}=\mathrm{O}), 1590,1540$ (aromatic ring), 1340 (C-N ), 1271 (C-O). ${ }^{1} \mathrm{H}-\mathrm{NMR}\left(500 \mathrm{MHz}, \mathrm{CDCl}_{3}\right)$ : see Table I. ${ }^{13} \mathrm{C}-\mathrm{NMR}\left(125 \mathrm{MHz}, \mathrm{CDCl}_{3}\right)$ : see Table II.

\section{2-(1-PIPERIDINYL)-3-(3-METHYL-2-BUTENYL)- 1, 4-NAPHTALENEDIONE (3)}

Dark red solid, mp 87.7-90.1 ${ }^{\circ} \mathrm{C}$. IR $\left(\mathrm{cm}^{-1}, \mathrm{KBr}\right)$ : $v_{\max } 1663(\mathrm{C}=\mathrm{O}), 1589,1539$ (aromatic ring), 1359 (C-N). ${ }^{1} \mathrm{H}-\mathrm{NMR}\left(500 \mathrm{MHz}, \mathrm{CDCl}_{3}\right)$ : see Table I. ${ }^{13} \mathrm{C}-\mathrm{NMR}\left(125 \mathrm{MHz}, \mathrm{CDCl}_{3}\right)$ : see Table II.
2-(1-PyrRolidinyL)-3-(3-METhYL-2-BUTENYL)1, 4-NAPHTHALENEDIONE (4)

Dark red syrup, IR $\left(\mathrm{cm}^{-1}, \mathrm{KBr}\right): v_{\max } 1668(\mathrm{C}=\mathrm{O})$, 1589 (aromatic ring), $1361(\mathrm{C}-\mathrm{N}) .{ }^{1} \mathrm{H}-\mathrm{NMR}(500 \mathrm{Mz}$, $\left.\mathrm{CDCI}_{3}\right)$ : see Table I. ${ }^{13} \mathrm{C}-\mathrm{NMR}\left(125 \mathrm{Mz}, \mathrm{CDCI}_{3}\right)$ : see Table II.

\section{LARVICIDAL ACTIVITY}

Larvicidal activity against Artemia salina was determined using a procedure described in the literature (McLaughlin 1991). Compounds 1-4 were tested in a concentration ranging from 1 to $500 \mathrm{ppm}$ and $\mathrm{LD}_{50}$ values were obtained using the Probit Program. Umbelliferone was included as a control (Table III).

Compounds 1-4 were tested against Aedes aegypti being placed in a beaker and dissolved 


\section{TABLE II}

${ }^{13} \mathrm{C}$ NMR and heteronuclerar long-range couplings $\left({ }^{2} J_{\mathrm{CH}}\right.$ and $\left.{ }^{3} J_{\mathrm{CH}}\right)$ spectral data for lapachol (1) and the enamine derivatives 2-4. Chemical shifts in $\delta_{\mathrm{C}}$ (ppm), in $\mathrm{CDCl}_{3}$ and TMS as internal standard.*

\begin{tabular}{|c|c|c|c|c|c|c|c|}
\hline & 1 & & 2 & & 3 & & 4 \\
\hline & $\delta_{\mathrm{C}}$ & $\delta_{\mathrm{C}}$ & ${ }^{2} J_{\mathrm{CH}}$ and ${ }^{3} J_{\mathrm{CH}}$ & $\delta_{\mathrm{C}}$ & ${ }^{2} J_{\mathrm{CH}}$ and ${ }^{3} J_{\mathrm{CH}}$ & $\delta_{\mathrm{C}}$ & ${ }^{2} J_{\mathrm{CH}}$ and ${ }^{3} J_{\mathrm{CH}}$ \\
\hline \multicolumn{8}{|l|}{$\mathrm{C}$} \\
\hline 1 & 181.71 & 182.60 & H-8 & 186.88 & $\mathrm{H}-8$ & 187.17 & $\mathrm{H}-8$ \\
\hline 2 & 152.75 & 154.74 & $2 \mathrm{H}-1^{\prime}$ & 164.47 & $2 \mathrm{H}-1$ & 165.85 & $2 \mathrm{H}-1^{\prime}$ \\
\hline 3 & 123.53 & 123.58 & $2 \mathrm{H}-1$ & 122.26 & $2 \mathrm{H}-1$ & 121.43 & $2 \mathrm{H}-1$ \\
\hline 4 & 184.54 & 184.58 & $\mathrm{H}-5,2 \mathrm{H}-1$ & 183.97 & $\mathrm{H}-5,2 \mathrm{H}-1^{\prime}$ & 183.79 & $\mathrm{H}-5,2 \mathrm{H}-1^{\prime}$ \\
\hline 9 & 129.48 & 129.85 & $\mathrm{H}-5, \mathrm{H}-7$ & 131.12 & $\mathrm{H}-7$ & 131.25 & $\mathrm{H}-5, \mathrm{H}-7$ \\
\hline 10 & 132.94 & 133.11 & H-6, H-8 & 134.55 & $\mathrm{H}-6, \mathrm{H}-8$ & 134.63 & $\mathrm{H}-6, \mathrm{H}-8$ \\
\hline $3^{\prime}$ & 133.80 & 133.40 & $2 \mathrm{H}-1^{\prime}, 3 \mathrm{H}-4^{\prime}, 3 \mathrm{H}-5$ ' & 131.42 & $2 \mathrm{H}-1^{\prime}, 3 \mathrm{H}-4^{\prime}, 3 \mathrm{H}-5^{\prime}$ & 131.67 & $2 \mathrm{H}-1^{\prime}, 3 \mathrm{H}-4^{\prime}, 3 \mathrm{H}-5$ ' \\
\hline \multicolumn{8}{|l|}{$\mathrm{CH}$} \\
\hline 5 & 126.78 & 126.62 & $\mathrm{H}-7$ & 126.01 & \multirow{5}{*}{$\mathrm{H}-8$} & 125.92 & $\mathrm{H}-7$ \\
\hline 6 & 134.83 & 134.61 & $\mathrm{H}-8$ & 133.86 & & 133.60 & \\
\hline 7 & 132.85 & 132.55 & H-5 & 131.12 & & 130.92 & \\
\hline 8 & 126.05 & 125.90 & H-6 & 125.32 & & 125.24 & H-6 \\
\hline $2^{\prime}$ & 119.71 & 120.35 & $2 \mathrm{H}-1^{\prime}, 3 \mathrm{H}-4^{\prime}, 3 \mathrm{H}-5$ ' & 123.18 & & 123.24 & $2 \mathrm{H}-1^{\prime}, 3 \mathrm{H}-4^{\prime}, 3 \mathrm{H}-5$ ' \\
\hline \multicolumn{8}{|l|}{$\mathrm{CH}_{2}$} \\
\hline $1^{\prime}$ & 22.64 & 22.70 & & 22.94 & & 22.93 & \\
\hline $6^{\prime}$ & - & 45.45 & & 44.85 & $2 \mathrm{H}-8$ & 45.54 & $2 \mathrm{H}-7$ ' and/or $2 \mathrm{H}-8$ \\
\hline 7', & - & 66.80 & & 22.94 & $2 \mathrm{H}-6$ & 24.69 & $2 \mathrm{H}-6$ ' and/or 2H-9' \\
\hline $8^{\prime}$ & - & - & & 22.56 & 2H-7', 2H-9' & 24.69 & $2 \mathrm{H}-6$ ' and/or $2 \mathrm{H}-7^{\prime}$ \\
\hline $9^{\prime}$ & - & 66.80 & & 22.94 & $2 \mathrm{H}-10$ & 45.54 & $2 \mathrm{H}-7^{\prime}$ and/or $2 \mathrm{H}-8$ \\
\hline $10^{\prime}$ & - & 45.45 & & 44.85 & $2 \mathrm{H}-8$ & - & \\
\hline \multicolumn{8}{|l|}{$\mathrm{CH}_{3}$} \\
\hline $4^{\prime}$ & 17.90 & 17.94 & $3 \mathrm{H}-5$ & 18.04 & $\mathrm{H}-2^{\prime}$ & 18.09 & $3 \mathrm{H}-5$ \\
\hline $5^{\prime}$ & 25.76 & 25.77 & $3 \mathrm{H}-4^{\prime}$ & 25.74 & $\mathrm{H}-2$ ' & 25.76 & $3 \mathrm{H}-4^{\prime}$ \\
\hline
\end{tabular}

*The number of bound hydrogens for each carbon signal was deduced by comparative analysis of HBBD- and DEPT- ${ }^{13} \mathrm{C}$ NMR spectra. Homonuclear $2 \mathrm{D}{ }^{1} \mathrm{H}-{ }^{1} \mathrm{H}-\mathrm{COSY}$ spectra of 1-4 and heteronuclerar $2 \mathrm{D}^{1} \mathrm{H}_{-}{ }^{13} \mathrm{C}_{-} \mathrm{COSY}-{ }^{n} J_{\mathrm{CH}}(\mathrm{n}=1, \mathrm{HMQC})$ of $\mathbf{1}$ were also used in these assignments.

in DMSO $(0.3 \mathrm{~mL})$ and water $(19.7 \mathrm{~mL})$ at concentrations ranging from 1 to $500 \mathrm{ppm}$ followed by addition of 50 larvae at the third stage. Mortality counts were made after 24 hours of treatment. A control solution was prepared using DMSO and water. Tests were done in tripiclate and the results are presented in Table III.

\section{Citotoxicity Assay Against A549 Human Tumor Cells}

Selective toxicity to hypoxic A549 human breast tumor cells was determined for all compounds using the MTT [3-(4,5-dimethylthiazol-2-yl)-2,5-diphenyl-2H-tetrazolium bromide] assay. Cells were 
TABLE III

Activity against Aedes aegypti and Artemia salina of lapachol (1) and the enamine derivatives (2-4).

\begin{tabular}{c|c|c}
\hline Compounds & $\begin{array}{c}\text { LD }_{50} \\
\text { (Aedes aegypti) }\end{array}$ & $\begin{array}{c}\mathrm{LD}_{50} \\
\text { (Artemia salina) }\end{array}$ \\
\hline $\mathbf{1}$ & 20.79 & 12.75 \\
$\mathbf{2}$ & 242.61 & 10.00 \\
$\mathbf{3}$ & 899.38 & 55.26 \\
$\mathbf{4}$ & 397.05 & 31.62 \\
Umbelliferone & - & 100.00 \\
\hline
\end{tabular}

\section{TABLE IV}

Cytotoxicity against A549 human breast tumor cells.

\begin{tabular}{c|c|c}
\hline Compounds & $\begin{array}{c}\mathrm{IC}_{50}(\mathrm{air}) \\
(\mathrm{mM})\end{array}$ & $\begin{array}{c}\mathrm{IC}\left(\mathrm{N}_{2}\right) \\
(\mathrm{mM})\end{array}$ \\
\hline 1 & $0.783 \pm 0.058$ & $1.0 \pm 3$ \\
20 & $.054 \pm 0.001$ & $0.091 \pm 0.032$ \\
31 & $.05 \pm 0.21$ & $0.84 \pm 0.11$ \\
40 & $.68 \pm 0.0059$ & $0.99 \pm 0.08$ \\
\hline
\end{tabular}

treated with drug for 3 hours at $37^{\circ} \mathrm{C}$ under aerobic or hypoxic $\left(\mathrm{N}_{2}\right)$ conditions. The drug was then removed and the cells allowed to proliferate for 3 days prior to MTT assay. The $\mathrm{IC}_{50}$ (air) and $\mathrm{IC}_{50}\left(\mathrm{~N}_{2}\right)$ values are the concentrations required to kill $50 \%$ of the cells under aerobic and under hypoxic conditions, respectively. The results are derived from at least three independent experiments and are presented in Table IV.

\section{RESULTS AND DISCUSSION}

Reaction of lapachol (1) with the amines morpholine, piperidine and pyrrolidine gave the 2-aminenaphthalenedione derivatives 2-(4-morpholinyl)-3(3-methyl-2-butenyl)-1,4-naphthalenedione (2), 2(1-piperidinyl)-3-(3-methyl-2-butenyl) -1,4-naphtalenedione (3) and 2-(1-pyrrolidinyl)-3-(3-methyl-2butenyl) -1,4-naphthalenedione (4) in relatively good yields. A solution of lapachol (1) in freshly re- distilled amine (morpholine or piperidine or pyrrolidine) was stirred for $6 \mathrm{~h}$ at room temperature. The excess amine was evaporated under vacuum and the residue recrystallized from a mixture of EtOAc/ hexane to yield the corresponding enamine derivatives 2 (94\%), 3 (79\%) and 4 (77\%). The reaction, is initiated by intermolecular attack of the nucleophile nitrogen on the 2-enol carbon atom (path a) or 2keto-carbonyl group (path $b$, much probable by the presence of a basic amine reagent) to produce the intermediates I and II, respectively, which dehydrate to give the corresponding enamine derivatives (2-4), as postulated and summarized in Figure 2.

The ${ }^{1} \mathrm{H}$ spectral data comparison (Table I) between lapachol (1) and the derivatives 2-4 indicate that the signals of the aromatic ring and side-chain attached at C-3 are practically unchanged and reveal the absence of the hydroxyl group at C-2 in the obtained products. Changes are mainly observed in the ${ }^{13} \mathrm{C}$ NMR spectral data (Table II), which show a deshielding effect at C-2 [ $\delta_{\mathrm{C}} 154.74$ (2), 164.47 (3), 165.85 (4)] when compared with lapachol $\left(1: \delta_{\mathrm{C}}\right.$ 152.75). The ${ }^{13} \mathrm{C}$ signals related to the amine moieties were observed at $\delta_{\mathrm{C}} 66.80\left(\mathrm{CH}_{2}-7^{\prime}\right.$ and $\mathrm{CH}_{2}$ 9') and $45.45\left(\mathrm{CH}_{2}-6\right.$ ' and $\left.\mathrm{CH}_{2}-10^{\prime}\right)$ for $2 ; \delta_{\mathrm{C}} 44.85$ ( $\mathrm{CH}_{2}-6$ ' and $\left.\mathrm{CH}_{2}-10^{\prime}\right), 22.94\left(\mathrm{CH}_{2}-7^{\prime}\right.$ and $\left.\mathrm{CH}_{2}-9^{\prime}\right)$ and $22.56\left(\mathrm{CH}_{2}-8^{\prime}\right)$ for $3 ; \delta_{\mathrm{C}} 45.54\left(\mathrm{CH}_{2}-6\right.$ ' and $\left.\mathrm{CH}_{2}-9^{\prime}\right)$ and $24.69\left(\mathrm{CH}_{2}-7^{\prime}\right.$ and $\left.\mathrm{CH}_{2}-8^{\prime}\right)$ for 4 (Table II). The ${ }^{1} \mathrm{H}$ (1D and $\left.2 \mathrm{D}^{1} \mathrm{H}-{ }^{1} \mathrm{H}-\mathrm{COSY}\right),{ }^{13} \mathrm{C}$ (HBBD and DEPT) and heteronuclear $2 \mathrm{D}^{1} \mathrm{H}_{-}{ }^{13} \mathrm{COSY}-{ }^{\mathrm{n}} J_{\mathrm{CH}}$ $(\mathrm{n}=1, \mathrm{HMQC} ; \mathrm{n}=2$ and 3, HMBC) NMR spectra were used to establish the structures and to assign unambiguously the chemical shifts for all the hydrogen and carbon atoms of 2-4 (Tables I and II). The presence of the amine moieties at C-2 was confirmed by the heteronuclear long-range couplings of the hydrogen (Table I) and carbon atoms (Table II) revealed by cross-peaks observed in the HMBC spectra corresponding to the spin-spin interactions of $\mathrm{H}-8\left[\delta_{\mathrm{H}} 7.98(2), 7.85(3)\right.$ and $\left.7.84(\mathbf{4})\right]$ and $\mathrm{C}-1$ [ $\delta_{\mathrm{C}} 182.60(\mathbf{2}), 186.88(3)$ and $\left.187.17(\mathbf{4}),{ }^{3} J_{\mathrm{CH}}\right]$, $2 \mathrm{H}-1$ ' $\left[\delta_{\mathrm{H}} 3.26(\mathbf{2}), 3.23(\mathbf{3})\right.$ and $\left.3.17(\mathbf{4})\right]$ and $\mathrm{C}-2$ $\left[\delta_{\mathrm{C}} 154.74(2), 164.47(3)\right.$ and $\left.165.85(4),{ }^{3} J_{\mathrm{CH}}\right], \mathrm{C}-$ $3\left[\delta_{\mathrm{C}} 123.58(2), 122.26(3)\right.$ and $\left.121.43(4),{ }^{2} J_{\mathrm{CH}}\right]$ 

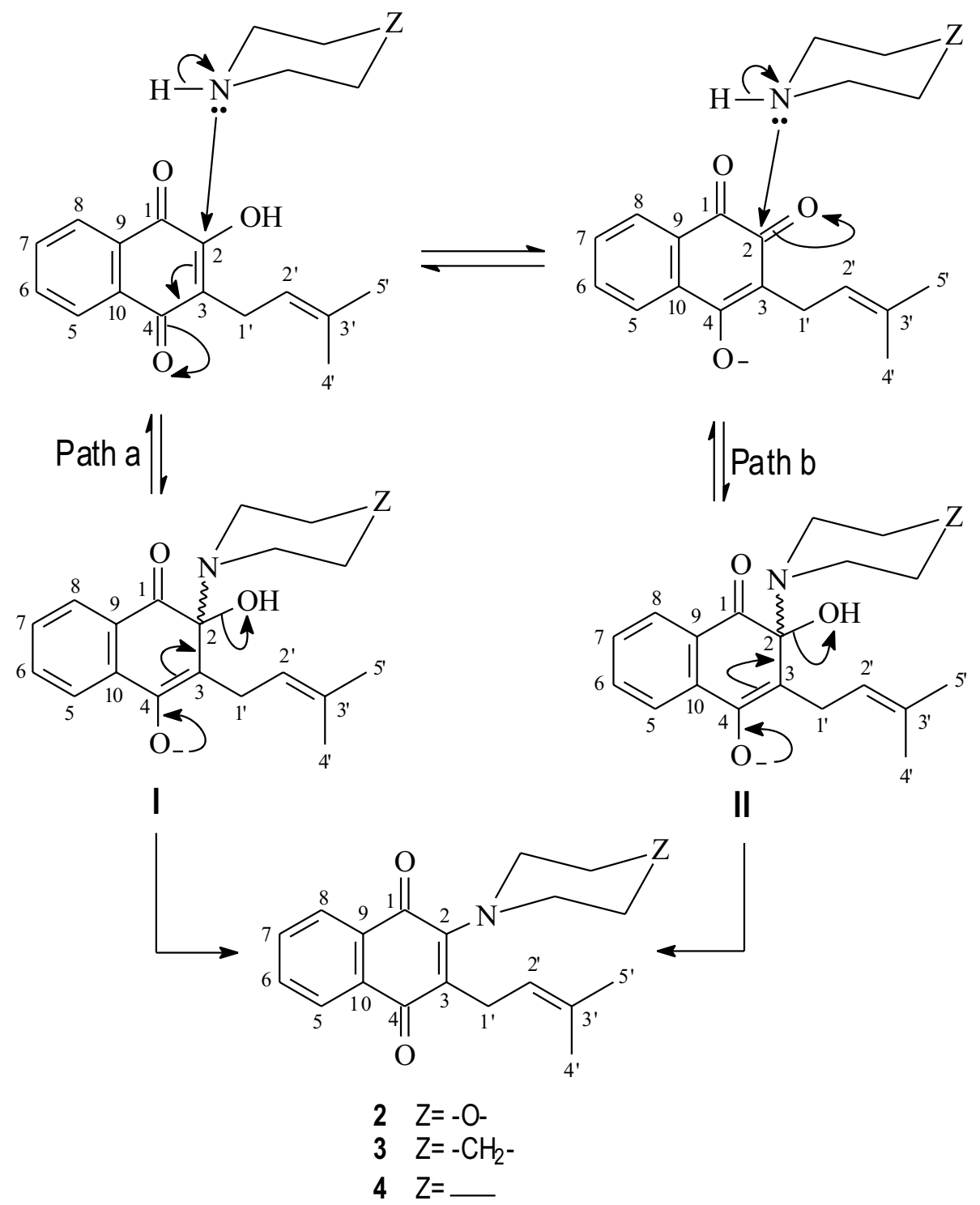

Fig. 2 - Proposed mechanism for the reaction of the amines morphiline, piperidine and pyrrolidine with lapachol (1) leading to the formation of the corresponding enamine derivatives $\mathbf{2 - 4}$.

and C-4 [ $\delta_{\mathrm{C}} 184.58(\mathbf{2}), 183.97(\mathbf{3})$ and $183.79(\mathbf{4})$, $\left.{ }^{3} J_{\mathrm{CH}}\right]$ and $\mathrm{H}-5\left[\delta_{\mathrm{H}} 8.07(2), 8.03(3)\right.$ and $\left.8.02(\mathbf{4})\right]$ and C-4 [ $\delta_{\mathrm{C}} 184.58(\mathbf{2}), 183.97(\mathbf{3})$ and $183.79(\mathbf{4})$, $\left.{ }^{3} J_{\mathrm{CH}}\right]$, as summarized in Figure 3. The differences observed in the chemical shifts of the carbon atoms C-1 $\left[\delta_{\mathrm{C}} 186.88(3)\right.$ and $\left.187.17(4)\right]$ and mainly C-2 $\left[\delta_{\mathrm{C}} 164.47(3)\right.$ and $\left.165.85(\mathbf{4})\right]$ of 3 and 4 when compared with those of $\mathbf{1}\left[\delta_{\mathrm{C}} 181.71(\mathrm{C}-1)\right.$ and 152.75 $(\mathrm{C}-2)]$ and 2 [ $\delta_{\mathrm{C}} 182.60(\mathrm{C}-1)$ and $\left.154.74(\mathrm{C}-2)\right]$ cannot be only accounted for by intramolecular electronic (inductive and mesomeric effects) and stereochemical arguments. However, the heteronuclear long-range couplings observed in the HMBC spectra (Table II and Figure 3) are clearly consistent with the proposed structures.

The ${ }^{13} \mathrm{C}$ chemical shifts of the enamine derivatives 2-4 were compared with data reported in the literature (Giasuddin et al. 1978, Breitmaier and 

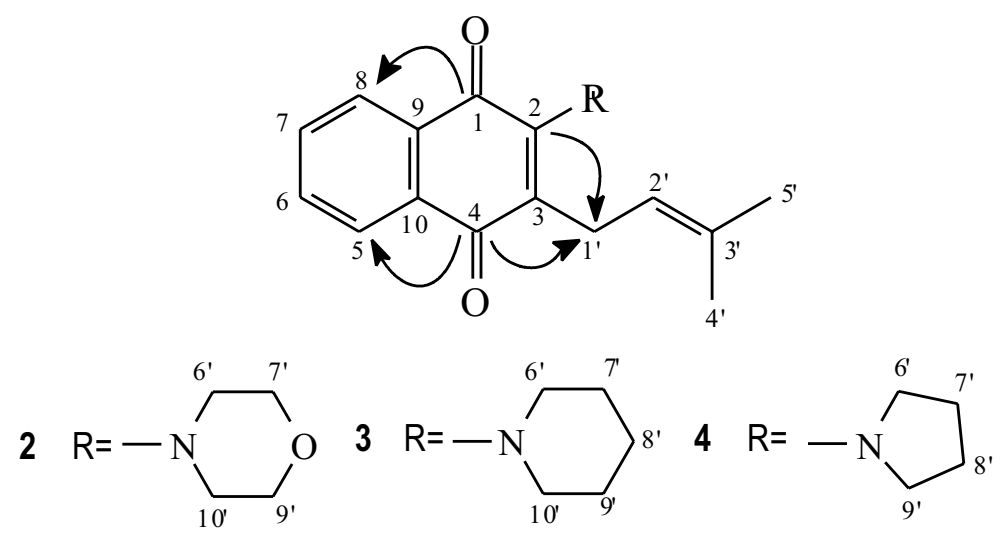

Fig. 3 - Selected HMBC correlations for compounds 1-4.

Voelter 1987) for compounds 5-10 (Figure 4). As shown in Figure 4, the electronic effect of a nitrogen atom [reduced electron density at the $\alpha$ carbon (C-3) by inductive withdrawal effect and increased electron density at the $\beta$ carbon by mesomeric effect] in 5 and $\mathbf{6}$ is practically identical, revealing $\Delta \delta_{\mathrm{C}}=1.1$ ppm. Major differences $\left(\Delta \delta_{\mathrm{C}}=2.4\right.$ to $\left.10.4 \mathrm{ppm}\right)$ were observed in the comparison of the ${ }^{13} \mathrm{C}$ chemical shifts of (Z)-1-pyrrolidinyl-1- (7), (Z)-morpholinyl1- (8), (E)-1-pyrrolidinyl-1- (9) and (E)-morpholinyl-1-propene (10), showing that, in fact, the electronic effects of the nitrogen atom in morpholinyl and pyrrolidinyl groups are significantly different, along with the anticipated shielding by a $\gamma$-effect which clearly allows to define the geometric isomer $(E$ or $Z$ ). Comparative analysis of the chemical shifts of the non-hydrogenated carbon atoms C-1 $\left[\delta_{\mathrm{C}}\right.$ $182.60(2), 186.88(3)$ and $187.17(4)]$ and C-2 $\left[\delta_{\mathrm{C}}\right.$ $154.74(2), 164.47(3)$ and $165.85(4)]$ of the enamine derivatives 2-4 revealed major electron density reduction at C-2 of $\mathbf{3}\left(\delta_{\mathrm{C}} 164.47\right)$ and $\mathbf{4}\left(\delta_{\mathrm{C}} 165.85\right)$, which are in accord with values $\delta_{\mathrm{C}} 163.4$ and 164.6 reported in the literature for the carbon atom C-3 of the model compounds $\mathbf{5}$ and $\mathbf{6}$, respectively (Figure 4). The chemical shifts of C-1 at $\delta_{\mathrm{C}} 186.88$ (3) and 187.17 (4) compared with those corresponding to C$4\left[\delta_{\mathrm{C}} 183.97(3)\right.$ and $\left.183.79(4)\right]$ show major electron density at C-4 and may be justified by the mesomeric effect involving the conjugated unpaired electrons of the nitrogen atom. However, the chemical shifts of these carbon atoms $\mathrm{C}-1$ and $\mathrm{C}-4$ in the compounds $\mathbf{1}$ and $\mathbf{2}$ cannot be justified on the basis of electronic effects (meanly mesomeric in this case), since they reveal a lower electron density at $\mathrm{C}-4\left[\delta_{\mathrm{C}} 184.54\right.$ (1) and $184.58(\mathbf{2})]$ than at $\mathrm{C}-1\left[\delta_{\mathrm{C}} 181.71(\mathbf{1})\right.$ and 182.60 (2)]. Thus, these data show significant differences when compared with the values observed for the compounds $\mathbf{3}$ and $\mathbf{4}$ above considered (Figure 4). Consequently, the electronic participation of the nitrogen atom of the morpholinyl group of $\mathbf{2}$ is different from that conferred by the pyrrolidinyl and piperidinyl groups. Comparative analysis of the ${ }^{13} \mathrm{C}$ NMR spectral data reported in the literature (Giasuddin et al. 1978, Breitmaier and Voelter 1987) for the model compounds 7-10 allowed again to observe different participation of the nitrogen atom of the morpholinyl group $\left(8: \delta_{\mathrm{C}} 140.0 ; 10: \delta_{\mathrm{C}} 141.0\right)$, indicating a major inductive effect at the $\alpha$ carbon and a minor mesomeric effect at the $\beta$ carbon (8: $\left.\delta_{\mathrm{C}} 107.5 ; 10: \delta_{\mathrm{C}} 95.8\right)$ than those revealed by compounds $7\left[\delta_{\mathrm{C}} 137.6(\mathrm{C}-\alpha)\right.$ and $\left.97.1(\mathrm{C}-\beta)\right]$ and $9\left[\delta_{\mathrm{C}}\right.$ $136.6(\mathrm{C}-\alpha)$ and $92.3(\mathrm{C}-\beta)$ ], as shown in Figures 4 and 5 .

All these data may be used to postulate the influence of other effects in the chemical shifts of C-1 and C-4 of lapachol (1) and its derivative 2, the same occurring with $\alpha$ and $\beta$ carbon atoms of the compounds $\mathbf{8}$ and $\mathbf{1 0}$ also containing the morpholinyl 

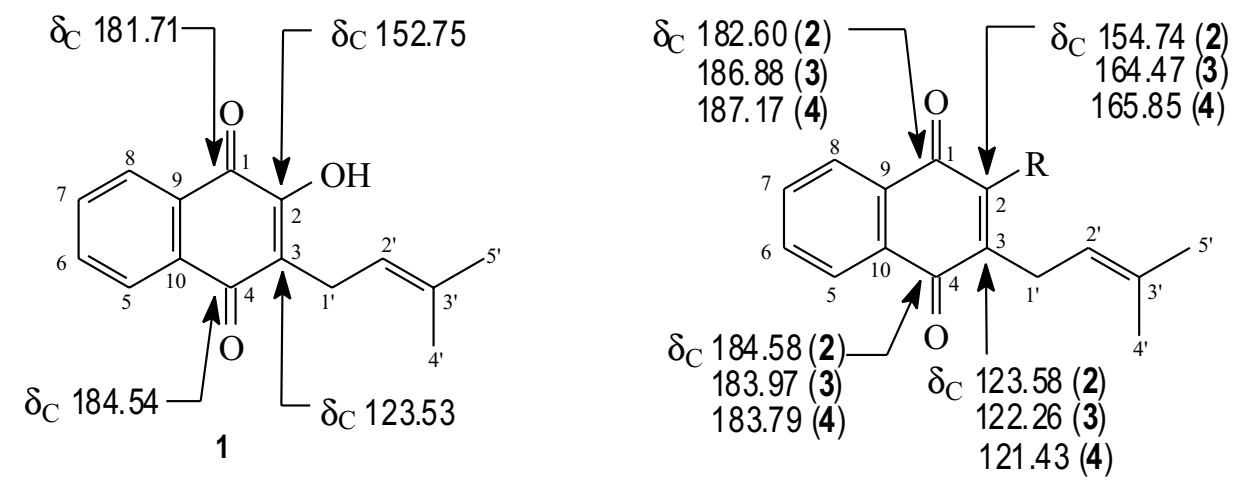

2<smiles>[R]N1[14CH2][14CH2]O[14CH2][14CH2]1</smiles>
3<smiles>[R]N1[C]CC[C]C1</smiles><smiles>[R]N1CCCC1</smiles>

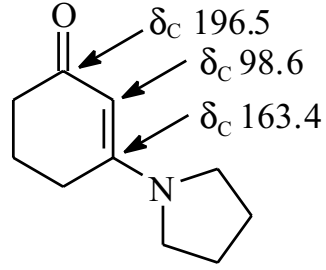

5

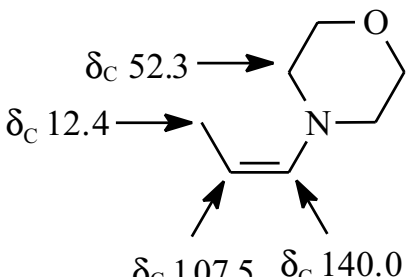

8

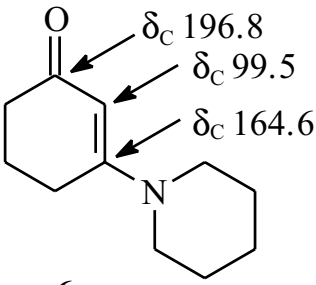

6

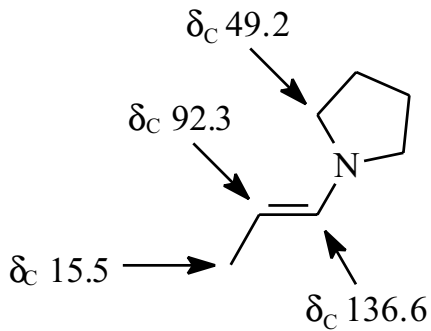

9

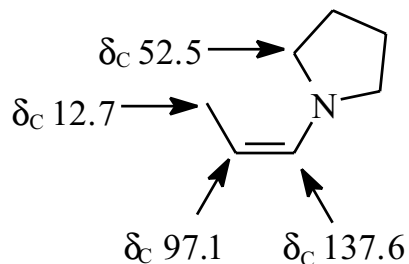

7

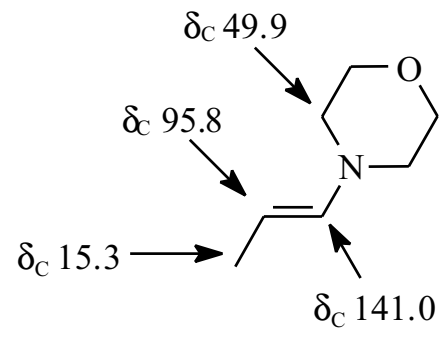

10

Fig. $4-{ }^{13} \mathrm{C}$ NMR spectral data of enamine derivatives 2-4 and model compounds 5-10 described in the literature (Giasuddin et al. 1978, Breitmaier and Voelter 1987).

group as 2. Among other possible contributing effects can be included the participation of intramolecular hydrogen bonding in $\mathbf{1}$ and intermolecular deuterium bonding involving the deuterium of the solvent $\mathrm{CDCl}_{3}$, the carbonyl at $\mathrm{C}-1$ and the nitrogen atom of $\mathbf{3}$ and $\mathbf{4}$ in the NMR experiments. However, in the case of $\mathbf{2}$, a repulsion between the non bonding electrons of chlorine (solvent) and the oxygen atom of the morpholinyl group prevents the formation of the deuterium bond (Figure 5) thus accounting for the minor changes of the chemical shifts of $\mathrm{C}-1$ and C-2 of $\mathbf{2}$ when compared with $\mathbf{3}$ and $\mathbf{4}$. 


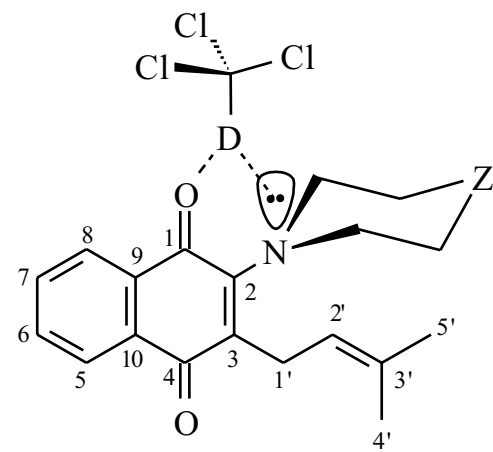

$2 Z=-0-$

$3 \mathrm{Z}=-\mathrm{CH}_{2}$

$4 \mathrm{Z}=$
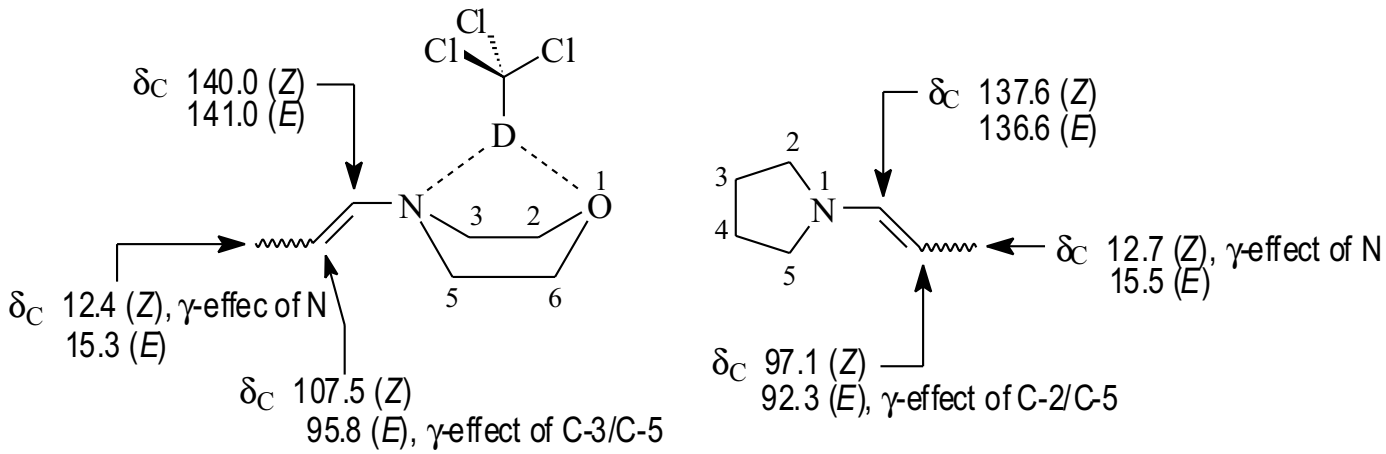

Z- (8) and $E-(10)$

Z- (7) and $E-(9)$

Fig. 5 - Intermolecular deuterium bonding of solvent $\mathrm{CDCl}_{3}$ with derivatives $\mathbf{2 - 4}$ and model compounds $\mathbf{7 - 1 0}$ described in the literature (Giasuddin et al. 1978, Breitmaier and Voelter 1987).

In the compounds $(Z)-(8)$ and (E)-1-morpholinyl-1-propene (10) the postulated speculative intermolecular deuterium bonding (Figure 5) may involve the nitrogen and oxygen atoms of the morpholinyl group in a bark conformation (8a and 10a). Thus, the mesomeric effect involving the conjugated unpaired electrons of the nitrogen is attenuated and the inductive withdrawal effect encouraged. In this structural situation, the influence of these effects induces an electron density reduction and, consequently, major chemical shifts for the $\alpha$ and $\beta$ carbon atoms of $\mathbf{8}$ and $\mathbf{1 0}$ when compared with those of 7 and 9 . This postulation requires additional investigations involving solvent, concentration and temper- ature variations, including methyl ether and acetyl derivatives of lapachol (1) and other analogous compounds, using dried samples to assure the absence of $\mathrm{H}_{2} \mathrm{O}$.

The larvicidal activity of compounds 1-4 using Artemia salina was evaluated (Table III). All compounds were found to be quite active. However, no significant difference was observed with substitution of the hydroxyl group by an amine at C-2 position. A slight decrease in activity was observed for compounds 3 and $\mathbf{4}$ compared to lapachol (1). $\mathrm{LD}_{50}$ data are summarized in Table III.

In a bioassay against Aedes aegypti, lapachol (1), with a $\mathrm{LD}_{50}$ of $20.79 \mathrm{ppm}$, was found to be 
more active than the amine derivatives with $\mathrm{LD}_{50}$ values of 242.6, 899.4 and $397.0 \mathrm{ppm}$, respectively, showing the importance of the hydroxyl group at the $\mathrm{C}-2$ position. The values of $\mathrm{LD}_{50}$ of these bioassays are also summarized in Table III.

The cytotoxicity against A549 human tumor cells was evaluated using compounds 1-4 (Table IV). On the basis of our experimental observations, lapachol (1) and their analogues $\mathbf{2 - 4}$ showed $\mathrm{mM}$ activity against cells kill, under aerobic as well as hypoxic conditions. Compound $\mathbf{2}$ is 10 fold more potent than its analogues, indicating the importance of the morpholine moiety in the toxicity of these compounds.

\section{CONCLUSION}

We have shown that lapachol (1) can be converted easily into enamine derivatives (2-4) using morpholine, piperidine and pyrrolidine. In a bioassay against Aedes aegypti, lapachol (1) was found to be more active than the amine derivatives $2-4$, showing the importance of the hydroxyl group at the C-2 position. The morpholine moiety in compound $\mathbf{2}$ may be important in the toxicity against A549 human tumor cells.

\section{ACKNOWLEDGMENTS}

The authors are grateful to CAPES (Coordenação de Aperfeiçoamento de Pessoal de Ensino Superior), CNPq (Conselho Nacional de Desenvolvimento Científico e Tecnológico) and FAPERJ (Fundação de Amparo à Pesquisa do Estado do Rio de Janeiro) for grants and research fellowships.

\section{RESUMO}

Uma síntese conveniente dos novos derivados enamínicos 2-(4-morfolinil)-3-(3-metil-2-butenil)-1,4-naftalenodiona, 2-(1-piperidinil)-3-(3-metil-2-butenil)-1,4-naftalenodiona e 2-(1-pirrolidinil)-3-(3-metil-2-butenil)-1,4-naftalenodiona foi conseguida de 2-hidroxi-3-(3-metil-2-butenil)-1,4-naftalenodiona (lapachol) natural e morfolina, piperidina e pirrolidina. As estruturas dos produtos foram estabelecidas principalmente pela análise de RMN, inclusive experimentos $2 \mathrm{D}$. Atividades biológicas destes produtos foram avaliadas contra Artemia salina, Aedes aegypti e citotoxicidade usando células humanas A549.

Palavras-chave: lapachol, derivados enamínicos, atividades biológicas.

\section{REFERENCES}

Breitmaier E and Voelter W. 1987. Carbon-13 NMR Spectroscopy: High-Resolution Methods and Applications in Organic Chemistry and Biochemistry. 3 Ed. Weinheim: VCH, p. 220 and 238-240.

Carvalho LH, Rocha EMM, Raslan DS, Oliveira AB AND KRettli AV. 1988. Natural and Synthetic Naphthoquinones Against Erythrocytic Stages of Plasmodium falciparum. Braz J Med Biol Res 21: 485-487.

Correia MP. 1984. Dicionário de Plantas Úteis do Brasil, Ministério da Agricultura. Brasil: Instituto Brasileiro de Desenvolvimento Florestal, vol. VI, p. 187.

Driscoll JS, Hazard GF, WoOd HB AND Goldin A. 1974. Structure-antitumor activity relationships among quinone derivatives. Cancer Chemother 4: $1-362$.

Fernandes-De-Oliveira M. 2000. Contribuição ao Conhecimento Químico das Espécies Tabebuia serratifolia Nichols e Tabebuia rosa Bertol. Tese de Doutoramento, Curso de Pós-graduação em Química Orgânica, Universidade Federal do Ceará, Fortaleza, Ceará, Brasil.

Giasuddin A, Hickmotт PW and Soelistyowati RD. 1978. Enamine Chemistry. Part 25. Preparation and Carbon-13 Magnetic Resonance Spectra of $N$ Alkyl-morpholines and -pyrrolidines. Comparison with the Carbon-13 Spectra of the Corresponding Acyclic Enamines. J Chem Soc Perkin II: 372-376.

Grazziotin JD, Schapoval EE, Chaves CG, Gleye J AND Henriques AT. 1992. Phytochemical and Analgesic Investigation of Tabebuia chrysotricha. J Ethnopharmacol 36: 249-251.

Lagrota M. 1983. Atividade Antivirótica do Lapachol. Rev Microbiol 14: 21-26.

Lopes JN, CRuz FS, CAMPo R, VAsconcellos ME, Sampaio MCR, Pinto AV and Gilbert B. 1978. In Vitro and in Vivo Evaluation of Toxicity of 1,4-Naphthoquinone and 1,2-Naphthoquinone Derivatives Against Trypanosoma cruzi. Ann Trop Med Parasitol 72: 523-531. 
McLaughlin JL. 1991. In: Method in Plant Biochemistry. London: Academic Press, Vol. 6, Assays for Bioactivity (Hostettman K, ed.), p. 1-32.

Naylor MA, JafFar M, Nolan J, Stephens MA, ButLer S, Patel KB, Everett AS, Adams GE and STRATFORD IJ. 1997. 2-Cyclopropylindoloquinones and Their Analogues as Bioreductively Activated Antitumor Agents: Structure-Activity in Vitro and Efficacy in Vivo. J Med Chem 40: 2335-2346.

Pan American Health Organization. 1994. Dengue and Dengue Hemorrhagic-Fever in the Americas: Guidelines for Prevention and Control no. 548, p. 14-21. Washington, D.C., USA.
Pinto AV, Pinto MCFR, Pellegrino JL and GilBERT B. 1977. Schistosomiasis mansoni-Blockage of Cercarial Skin Penetration by Chemical Agents. 1. Naphtoquinones and Derivatives. Trans Royal Soc Trop Med Hyg 71: 133-135.

Pinto AV, Ferreira VF, Capella RS, Gilbert B, PINTO MCFR AND Silva JS. 1987. Activity of Some Naphthoquinones on Blood Stream Forms of Trypanosoma cruzi. Trans Royal Soc Trop Med Hyg 81: 609-610. 